\title{
Carbon budget recovery and role of coarse woody debris in post-logging forest ecosystems of Southern Siberia
}

\author{
Recuperación del balance de carbono y el rol de los residuos leñosos de gran tamaño en \\ ecosistemas forestales post-cosecha del sur de Siberia
}

\section{Ludmila Mukhortova}

Siberian Branch of Russian Academy of Science, VN Sukachev Institute of Forest, Krasnoyarsk, Russia, l.mukhortova@gmail.com

\author{
SUMMARY
}

Forest harvesting is a major human-caused disturbance affecting carbon budgets in forest ecosystems. This study was concerned with post-logging carbon pool changes in Scots pine (Pinus sylvestris) and Siberian fir (Abies sibirica) stands. To understand carbon budget recovery trends following logging, carbon stock and fluxes were measured in stands differing in time since logging. In both Scots pine and fir stands disturbed by logging, the tree phytomass contribution to the carbon budget decreased drastically, whereas the coarse woody debris (CWD) carbon pool exhibited a marked increase. Sixty years following logging, the Scots pine stand carbon storage was almost $70 \%$ of that prior to logging and the ratio between the phytomass and soil organic matter was the same as before the disturbance. While the phytomass carbon showed a similar trend in the fir stand of the same age, it was less than on the control stand. In a 50-55-year-old fir stand, 26 years since harvesting, the phytomass carbon recovered only by $15 \%$. Siberian fir and Scots pine logging sites differed in CWD loading and decomposition rate. The phytomass dynamics and CWD loading values obtained suggest that Scots pine stands which have experienced logging are most likely carbon sinks, as was clear from the phytomass production exceeding organic matter decomposition-caused fluxes. Conversely, logged fir ecosystems are likely to be sources of carbon to the atmosphere due to a large CWD loading, faster rate of its decomposition, and slow phytomass increment.

Key words: carbon budget, logging, phytomass, coarse woody debris, decomposition.

\section{RESUMEN}

La explotación forestal es un importante disturbio de origen humano que afecta el balance de carbono en ecosistemas forestales. Este estudio se concentró en los cambios de las reservas de carbono post-cosecha de rodales de pino silvestre (Pinus sylvestris) y abeto siberiano (Abies sibirica). Para entender la recuperación del balance de carbono después de la cosecha, se midió el stock y flujo de carbono en diferentes momentos posterior a la cosecha. En ambos rodales explotados, la contribución de la fitomasa forestal al balance de carbono disminuyó drásticamente, mientras que la reserva de carbono en los residuos leñosos de gran tamaño (CWD) exhibió un marcado incremento. Sesenta años después de la cosecha, el almacenamiento de carbono en rodales de pino silvestre fue casi del $70 \%$ respecto a lo de antes de cosecha. El radio entre la fitomasa y la materia orgánica del suelo fue el mismo al de antes de la perturbación. Si bien la fitomasa de carbono mostró una tendencia similar en el rodal de abeto, éste fue menor que el rodal control. En un rodal de abeto de 50-55 años de edad, 26 años desde la explotación, el carbono de la fitomasa se recuperó en sólo un 15 \%. Rodales explotados de abetos de Siberia y de pino silvestre difirieron en la carga de CWD y en la tasa de descomposición. La dinámica de la fitomasa y los valores de carga de CWD sugieren que los rodales explotados de pino silvestre son probablemente sumideros de carbono, como se desprende de la producción de fitomasa que excede los flujos de materia orgánica causados por descomposición. A la inversa, rodales de abeto explotados son probablemente fuentes de carbono a la atmósfera debido a la gran carga de CWD, la tasa más rápida de descomposición y el lento incremento de fitomasa.

Palabras clave: balance de carbono, explotación forestal, fitomasa, restos leñosos, descomposición.

\section{INTRODUCTION}

Different types of disturbances of forest ecosystems, which are recognized to be globally important carbon sinks, often alter the ratio between the rates of phytomass productivity and organic matter decomposition and, as a result, induce carbon budget changes.

Forest harvesting is a major anthropogenic disturbance having profound and prolonged impacts on forest ecosystems (Bergstedt and Milberg 2001). Cutting of trees alters the forest structure and functional attributes of forest ecosystems (De Grandpre et al. 2000). The resulting carbon budget changes are sometimes as far as conversion of such ecosystems from carbon sinks to carbon sources.

This study focused on estimating a long term dynamics of carbon pools in Pinus sylvestris L. (Scots pine) and Abies sibirica Ledeb. (Siberian fir) stands fragmented by logging in the east of Baikal region. 


\section{METHODS}

A total of six sites differing in time since logging were sampled; three in Pinus sylvestris and the other three in Abies sibirica stands. Each logged site consisted of several logging compartments with skidding trails in between (table 1).

The organic matter pools on the logged sites were measured in the sample plots representative of the logging compartments, and on the skidding trails. The skidding trails and the logging compartments of the plots were 5-6 $\mathrm{m}$ and $30 \mathrm{~m}$ wide, respectively. The stand phytomass was calculated based on the stem wood volume, the wood density, and conversion ratios available for tree crowns and roots (Stakanov et al. 1994). We calculated ground vegetation and forest litter biomass using the layer weight data obtained from $20 \times 20 \mathrm{~cm}$ sample plots $(\mathrm{n}=10)$. To calculate that of fine roots and detritus, $20-\mathrm{cm}$ deep $20 \mathrm{x}$ $20 \mathrm{~cm}$ soil pits were made. Soil humus contents were measured using Walkley-Black wet oxidation technique.

To obtain coarse woody debris biomass, including down deadwood, tree stumps, and coarse roots, we recorded the diameters, at both ends, and length of each log, as well as each tree stump diameter and length. Additionally, the decomposition class of each log and each tree stump was determined through the applications of methodology described by Klimchenko (2005). Dead coarse root biomass was calculated based on the stump numbers and size and on the volume of the logs of similar diameter using conversion ratios (Stakanov et al.1994). Each coarse woody debris element was assigned to one out of three decay classes based on visual estimation of its physical condition. Wood density in each decay class was measured and used to determine coarse woody debris loading and decomposition rate.

\section{RESULTS}

The 180-year-old undisturbed Pinus sylvestris stand found on the podzol soil contained 116.5 $\mathrm{Mg} \mathrm{ha}^{-1}$ of carbon (figure 1A), with the above- and bellow-ground phytomass accounting for up to $56.6 \%$ of the total carbon storage (figure 1B). Plant detritus contributed $29.7 \%$, and about $14.0 \%$ of the total carbon was allocated in the soil humus. In the recently logged Pinus sylvestris sites, the carbon allocated in the live phytomass ranged $7.6 \%$ to $14.6 \%$ of the total carbon, whereas the phytodetritus and humus contribution was twice to triple that in the control. These changes were a result of wood extraction from these stands. The total carbon storage in these disturbed sites was up to $60.8 \mathrm{Mg} \mathrm{ha}^{-1}$, half as much as in the undisturbed site. However, in the 60-year-old logging site of Pinus sylvestris, the total carbon storage increased by half to twice and the contribution of living phytomass, phytodetritus, and soil humus almost reached the level in the undisturbed stand (58\%, $23 \%$, and $19 \%$, respectively).

Quite different dynamics of the organic matter pools was observed for Abies sibirica stands growing on podbur soil, which is more fertile than Podzol (figure 2A). Although the total carbon storage in the undisturbed 220-year-old Abies sibirica site was about the same as in the undisturbed Pinus sylvestris stand, $129.8 \mathrm{Mg} \mathrm{ha}^{-1}$, the storage structure was different (figure 2B). Like in the Pinus sylvestris sites, the live phytomass accounted for half of the total carbon here, but the plant detritus contained much less $(17.5 \%)$ and soil humus considerably more (32\%) carbon. After logging, in the three-year-old Abies sibirica logged site, the phytomass contribution decreased by more than an order of magnitude (down to $3.6 \%$ ) and the relative humus contribution increased to $44.8 \%$. The total carbon on this site even increased due to a five-fold increase in coarse woody debris stock induced by logging. In the 26-year-old Abies sibirica logged site, which supported a 50-55- year-old stand, the carbon storage ratio between the main organic matter pools did not reach that obtained for the undisturbed Abies sibirica stand. The contribution of the live phytomass was twice that in the three-year-old logging site. The coarse woody debris pool

Table 1. Sample stand characteristics. Características de los rodales muestreados.

\begin{tabular}{|c|c|c|c|c|c|c|}
\hline Sites & $\begin{array}{l}\text { Time since } \\
\text { logging (years) }\end{array}$ & $\begin{array}{l}\text { Major woody } \\
\text { species }\end{array}$ & $\begin{array}{l}\text { Stand age } \\
\text { (years) }\end{array}$ & $\begin{array}{c}\text { Average stand } \\
\text { height }(\mathrm{m})\end{array}$ & $\begin{array}{l}\text { Average tree } \\
\text { diameter }(\mathrm{cm})\end{array}$ & $\begin{array}{l}\text { Standing volume } \\
\qquad\left(\mathrm{m}^{3} \mathrm{ha}^{-1}\right)\end{array}$ \\
\hline \multicolumn{7}{|c|}{ Pinus sylvestris forests, Ulan-Burgasy Mt. Ridge } \\
\hline Control & - & Pinus sylvestris & $180 \pm 20$ & $19.5 \pm 1.1$ & $22.0 \pm 2.2$ & 180 \\
\hline Clear-cut & 60 & Pinus sylvestris & $60 \pm 4$ & $10.3 \pm 0.7$ & $9.8 \pm 1.3$ & 122 \\
\hline Recently logged site & 2 & Pinus sylvestris & - & - & - & 20 \\
\hline \multicolumn{7}{|c|}{ Abies sibirica forests, Khamar-Daban Mt. Ridge } \\
\hline Control & - & Abies sibirica & $220 \pm 35$ & $12.4 \pm 1.8$ & $16 \pm 2.6$ & 199.4 \\
\hline Logged site & 26 & Abies sibirica & $55 \pm 5$ & $4.7 \pm 0.5$ & $6.1 \pm 1.2$ & 17.5 \\
\hline Recently logged site & 3 & Abies sibirica & - & - & - & - \\
\hline
\end{tabular}


A

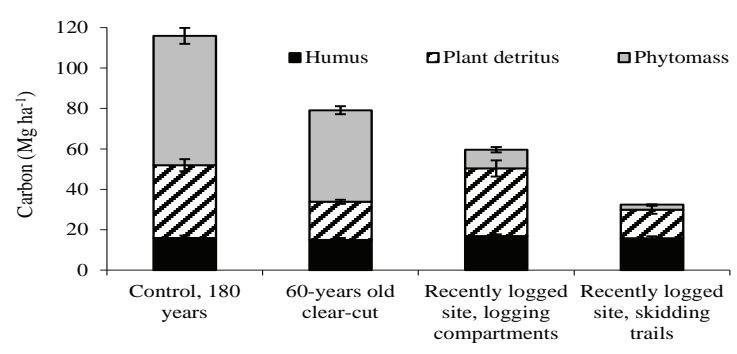

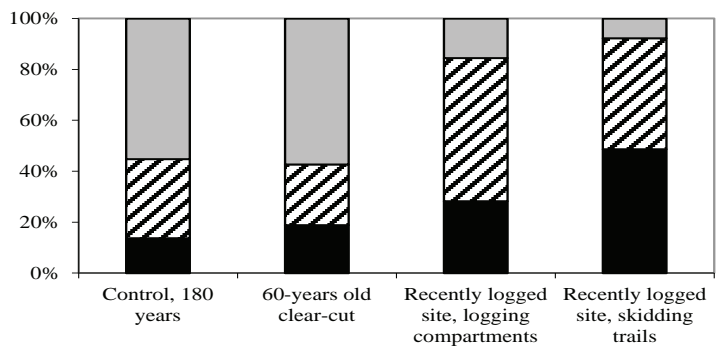

Figure 1. Carbon storage (A) and contributions of the main pools (B) in the logged Scots pine sites.

Almacenamiento de carbono (A) y contribuciones de las principales reservas (B) en rodales explotados de pino silvestre.
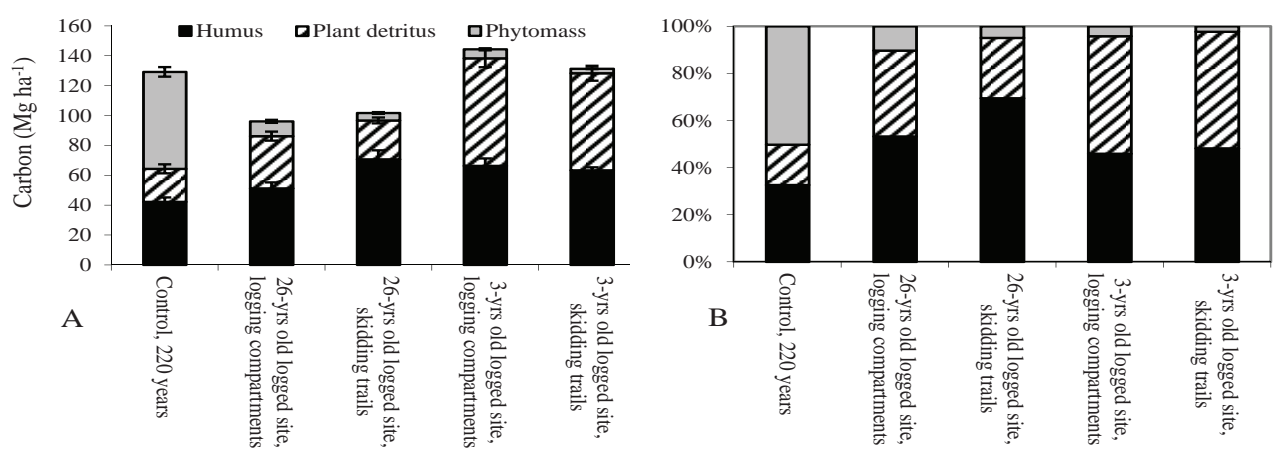

Figure 2. Carbon storage (A) and contributions of the main pools (B) in the logged Siberian fir sites.

Almacenamiento de carbono (A) y contribuciones de las principales reservas (B) en rodales explotados de abeto siberiano.

contributed more than triple less (35.7\%) to total carbon stock, whereas soil humus contribution was still relatively high (54.2\%)

The total loading of coarse woody debris was about 13.3 $\mathrm{Mg} \mathrm{ha}^{-1}$ of carbon in the undisturbed Pinus sylvestris site, which amount was about equal to that in the logging compartments of the recently logged site $\left(12.9 \mathrm{Mg} \mathrm{ha}^{-1}\right.$ of carbon) vs. at most $1.2 \mathrm{Mg} \mathrm{ha}^{-1}$ of carbon on the skidding trails. In the 60-year-old clearcut site, the total coarse woody debris stock was only 6.2 $\mathrm{Mg} \mathrm{ha}^{-1}$ of carbon. Coarse woody debris loading in the compartments of the recently logged Pinus sylvestris site was almost twice that of live tree biomass. In the 60-yr-old clear-cut an on the control site with a 180-yr-od Pinus sylvestris stand, the coarse woody debris contribution to the total carbon decreased to become $13-18 \%$ of that of the live phytomass (figure 3).

The skidding trails on the recently logged Abies sibirica site stood out for the highest coarse woody debris load, 61.6 $\mathrm{Mg} \mathrm{ha}^{-1}$ of carbon (figure 3), which amount accounted for about $63.8 \%$ and $80.5 \%$ of the total plant organic matter in the logging compartments and skidding trails, respectively.

The undisturbed Pinus sylvestris and Abies sibirica sites were similar in coarse woody debris contribution to the total organic matter, about $10.3 \%$ and $12.5 \%$, respectively, i.e. about $34-38 \%$ of the total phytodetritus pool of these site.

\section{DISCUSSION}

Carbon is accumulated in forests in three main pools: living phytomass, dead plant residues, and soil humus. These pools are the major forest carbon budget controls. Living phytomass is the main sink of the atmospheric carbon, plant residues are its main source, and soil humus is one of the largest carbon reservoirs, because of a very low rate of turnover of its components. The changes of the ratio between these three pools often result in changing of the carbon-flux pattern in an ecosystem. Increasing plant detritus enhances carbon efflux, whereas phytomass losses lead to decreases in the amount of fixed carbon and in stand production.

On the logging sites the plant detritus increase most prominently due to the presence of high amounts of logging slash. The rate of coarse woody debris decomposition calculated based on the log wood density in the chronosequences appear to differ between the logged Abies sibirica and Pinus sylvestris sites. The decomposition rate constant calculated using a single exponential model (Olson 1963) is 0.025 per year for the Abies sibirica logs and 0.0069 per year for Pinus sylvestris logs. These values are comparable to those reported for these woody species in literature (Harmon et al. 2000, Yatskov et al. 2003, Trefilova et al. 2009). 

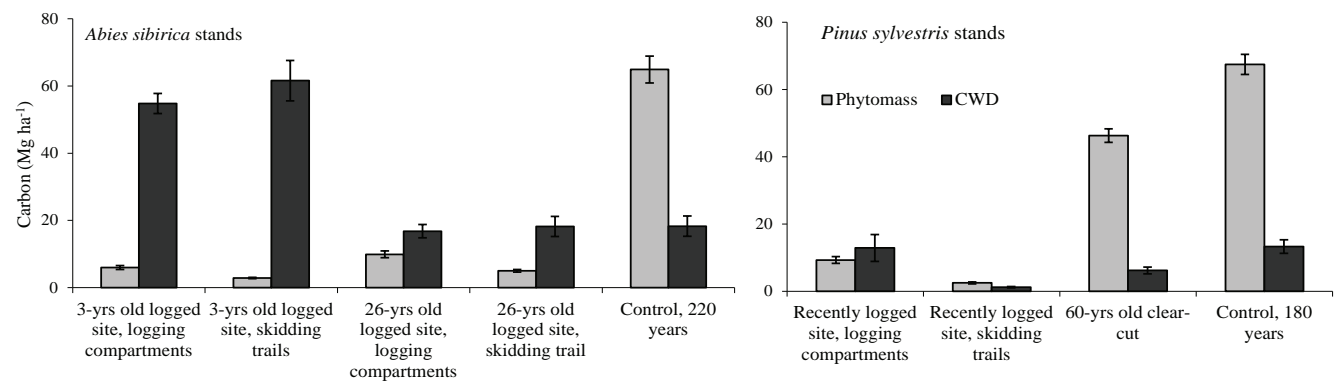

Figure 3. Dynamics of phytomass and CWD stock in recovery lines of fir and pine forests. Dinámica de fitomasa y stock de CWD en líneas de recuperación de bosques de abeto y pino.

Based on the coarse woody debris loading and decomposition rate values obtained, the coarse woody debris pool at the recently logged Abies sibirica site is likely to decrease averagely by $41 \%$ (i.e. by about $25 \mathrm{Mg} \mathrm{ha}^{-1}$ of carbon) in next 26 years. This carbon will most likely return to the atmosphere, because no soil humus carbon increment was observed in the Abies sibirica chronosequence. Such huge an efflux will obviously not be compensated by future phytomass, as its increment measured on the 26-year-old logged Abies sibirica site was only 2-4 $\mathrm{Mg} \mathrm{ha}^{-1}$ of carbon and generally did not exceed $10 \mathrm{Mg} \mathrm{ha}^{-1}$ (figure 3).

The efflux from the decomposing coarse woody debris found on the recently logged Pinus sylvestris site is presumed to be substantially lower due to a lower coarse woody debris amount and rate of decomposition as compared to the Abies sibirica sites. The organic carbon efflux from decomposing Pinus sylvestris coarse woody debris is, thus, predicted to reach only $2 \mathrm{Mg} \mathrm{ha}^{-1}$ of carbon during the next 60 years, which amount is much less than the phytomass increment obtained for this site for the same time period (figure 3)

Coarse woody debris buildups and increases in the net carbon efflux have been reported by other researchers (Plaut 2002, Howard et al. 2004, Liu et al. 2006). A comparison between the post-logging succession series of the two woody species show that logged Abies sibirica stands remain a carbon source to the age of 55-60, whereas logged Pinus sylvestris sites become carbon sinks by this age due to high phytomass production, low logging slash amount and rate of decomposition.

\section{CONCLUSIONS}

Logging in Pinus sylvestris and Abies sibirica stands is found to alter the ratio between the main organic carbon pools and to reduce drastically tree phytomass contribution to logged site carbon budgets.

In the recently logged Pinus sylvestris and Abies sibirica sites, the carbon-related significance of soil organic matter pools (phytodetritus and humus) increase considerably. These two woody species appear to differ in the time needed for the ratio to recover back to pre-logging. In the 60-year-old logged Pinus sylvestris sites, the stored carbon is as high as almost $70 \%$ of that on the control site. The ratio between phytomass and soil organic matter recover back to pre-logging by this age. The phytomass carbon also increase in the disturbed Abies sibirica stand of the same age, though it does not reach the level on the control stand. In the 50-55-year-old stand, carbon recover only by $15 \%$ of its pre-logging pool.

The decomposition rate of Pinus sylvestris logs is significantly lower as compared with Abies sibirica logs and coarse woody debris. Slow post-logging phytomass recovery and rapid decomposition of a huge amount of logging slash make the disturbed Abies sibirica sites potential sources of carbon to the atmosphere. Conversely, the logged Pinus sylvestris sites become carbon sinks due to the high stand growth rate, low logging slash load and decomposition rate.

\section{ACKNOWLEDGEMENTS}

This research was supported by the Russian Foundation for Basic Research (RFBR) (Grants 10-04-00337 and 11-04-01884) and by joint grants of RFBR and Krasnoyarsk Regional Foundation for Science and Technical Development (Projects 11-04-98008 and 11-04-98089).

\section{REFERENCES}

Bergstedt J, P Milberg. 2001. The impact of logging intensity on field-layer vegetation in Swedish boreal forests. Forest Ecology and Management 154: 105-115.

De Grandpre L, JL Morissette, S Gauthier. 2000. Long-term postfire changes in the northeastern boreal forest of Quebec. Journal of Vegetation Science 11: 791-800.

Harmon ME, ON Krankina, J Sexton. 2000. Decomposition vectors: a new approach to estimating woody detritus decomposition dynamics. Canadian Journal of Forest Research 30: 74-84

Howard EA, S Gower, JA Foley, ChJ Kucharik. 2004. Effects of logging on carbon dynamics of a jack pine forest in Saskatchewan, Canada. Global Change Biology 10: 1267-1284 DOI: $10.1111 /$ j.1365-2486.2004.00804.x 
Klimchenko AV. 2005. Carbon accumulation in logs of larch forests in Northern taiga of Central Siberia. Journal of Forestry 5: 33- 34. (in Russian)

Liu WH, DM Bryant, LR Hutyra, SR Saleska, E Hammond-Pyle, D Curran, SC Wofsy. 2006. Woody debris contribution to the carbon budget of selectively logged and maturing midlatitude forests. Oecologia 148: 108-117.

Olson JS. 1963. Energy storage and the balance of producers and decomposers in ecological systems. Ecology 44: 322-331.

Plaut J. 2002. Carbon accumulation and distribution in a boreal mixedwood logged chronosequence near Wabowden, Manitoba. Senior Thesis of Bachelor of Science in Environmental Studies. Providence, RI, USA. Brown University,
Center for Environmental Studies. 77 p.

Stakanov VD, VA Alekseev, IA Korotkov, BL Klimushin. 1994. Method of determination of phytomass and carbon reserves in forest communities. In Alekseev VA, RA Berdsi eds., Carbon in forest and marsh ecosystems, Krasnoyarsk: VN Sukachev Institute of Forest, Siberian Branch, Russian Academy of Sciences. p. 48-66. (in Russian)

Trefilova OV, EF Vedrova, PA Oskorbin. 2009. Stock and structure of coarse woody debris in pine forests of Yenisey Plain. Journal of Forest Science 4: 16-24. (in Russian)

Yatskov M, ME Harmon, ON Krankina. 2003. A chronosequence of wood decomposition in the boreal forests of Russia. Canadian Journal of Forest Research 33: 1211-1226.

Recibido: 24.05.12

Aceptado: 10.10 .12 